Telisik

\title{
MENELUSURI JEJAK UGM DALAM GERAKAN REFORMASI INDONESIA DARI SUMBER ARSIP STATIS KHAZANAH ARSIP UGM
}

\author{
Musliichah, A.Md. S.IP., M.A. \\ Arsip Universitas Gadjah Mada \\ (musliichah@ugm.ac.id)
}

\begin{abstract}
INTISARI
Peristiwa reformasi yang membawa perubahan besar dalam sejarah perjalanan Bangsa Indonesia dapat digunakan sebagai proses pembelajaran. Mempelajari masa lalu bisa menjadi proses pembelajaran. Sejarah akan lebih efektif sebagai proses pembelajaran apabila tidak hanya sekedar dibaca tetapi dikaji dan diteliti. UGM sebagai universitas perjuangan yang lahir di kancah revolusi menjadi bagian dari alat perjuangan Bangsa Indonesia, terpanggil turut serta dalam gerakan perjuangan pada masa reformasi. Berdasarkan sumber-sumber arsip khazanah Arsip UGM dapat digambarkan gerakan reformasi yang terjadi di UGM, mencakup elemen-elemen yang terlibat di dalamnya yaitu dosen, mahasiswa, lembaga UGM, dan unit kerja UGM, serta karyawan; serta bentukbentuk kegiatan reformasi yaitu aksi demonstrasi, kajian, penyelenggaraan forum-forum ilmiah, penyampaikan sikap, penyampaian rekomendasi, dan pemberitaan.
\end{abstract}

Kata kunci: aksi reformasi, arsip statis, sumber sejarah, UGM

\begin{abstract}
Events reforms brought major changes in the history of the Indonesian nation can be used as a learning process. Studying the past can be a learning process. History will be more effective as a learning process where not only read but studied and researched. UGM as universities struggle born in the midst of a revolution becomes part of the Indonesian nation struggles tool. UGM called to participate in the reform movement during the struggle. Research based on Arsip UGM Archives can be described what happened reform movement in the UGM; elements that are involved in it (student, lecture, UGM institutions and UGM units, and employees); and forms of reform activities like demonstrations, research, organization of scientific forums, statement, recommendations, and media announcement.
\end{abstract}

Keywords: archives, historical sources, reform action, UGM 


\section{PENGANTAR}

Universitas Gadjah Mada (UGM) didirikan pada masa yang sangat sulit yaitu dalam kancah revolusi perang kemerdekaan. Kondisi UGM saat berdiri pada masa revolusi nasional adalah terjadi blokade yang sangat hebat, jumlah dosen jumlah sangat sedikit, alat-alat perkuliahan sangat sederhana, dan serba kekurangan. Segala keterbatasan dan kekurangan ini tidak menghalangi perjuangan UGM. Berkat keuletan, kebijaksanaan dan ketulusan hati para pembangun dan pendukungnya, UGM berhasil didirikan. Pada tahun 1951 dinyatakan bahwa dalam diri UGM telah mulai tampak sifatnya sebagai sebuah pusat kebudayaan kebangsaan, sebagai sebuah bukti keuletan, kecerdasan, dan keluhuran Bangsa Indonesia. (Keputusan Presiden No. 253 Tahun 1951).

UGM lahir dalam kancah revolusi sebagai salah satu alat perjuangan Bangsa Indonesia. UGM sebagai universitas kerakyatan, universitas kebudayaan, dan universitas pancasila selalu diharapkan kontribusinya dalam pergerakan perjuangan Bangsa Indonesia. Tumbangnya orde baru diawali dengan gerakan reformasi. Gerakan yang muncul di awal tahun 1998 tersebut menjadi salah satu sejarah penting perjalanan Bangsa Indonesia. Lahirnya gerakan reformasi dipelopori oleh aksi mahasiswa UGM yang dilakukan terus-menerus sejak bulan Maret 1998. Aksi tersebut terus meluas, mendapat dukungan dari UGM baik para dosen maupun Pimpinan UGM. (Purwanto, dkk., 1999:124).

Peristiwa bersejarah yang terjadi sejak 19 tahun lalu dan berlangsung selama beberapa tahun tersebut tentu telah terdokumentasi dalam berbagai bentuk rekaman informasi/arsip. Rekaman jejak pergerakan UGM tersebut menjadi aset penting dalam proses pembelajaran bangsa Indonesia. UGM sejak tahun 2004 telah memiliki lembaga kearsipan perguruan tinggi bernama Arsip UGM. Tugas dan tanggung jawab Arsip UGM di antaranya adalah mengelola arsip-arsip statis terkait UGM yang dapat digunakan sebagai sumber sejarah. Menelisik kembali sejarah perjalanan UGM dalam gerakan reformasi dari sumber-sumber sejarah yang ada di Arsip UGM menjadi salah satu upaya untuk refleksi dan introspeksi perjalanan perjuangan Bangsa, serta mengkaji sumber-sumber sejarah terkait reformasi yang dapat digunakan sebagai guide oleh para sejarawan, politikus, maupun peneliti bidang keilmuan lainnya.

UGM sebagai universitas perjuangan yang lahir dalam kancah revolusi menjadi salah satu elemen penting dalam gerakan perjuangan Bangsa Indonesia. Penelitian ini ingin mengetahui keterlibatan UGM dalam gerakan reformasi Indonesia, unsurunsur UGM yang terlibat dalam gerakan tersebut dan sekaligus untuk mengetahui sumber-sumber sejarah terkait reformasi yang ada di UGM.

Tujuan dan manfaat penelitian ini adalah sebagai berikut:

1. Mengetahui peran UGM baik secara kelembagaan maupun pribadi para sivitas akademika UGM dalam gerakan reformasi di Indonesia;

2. Mengetahui sumber-sumber sejarah tekait UGM dalam gerakan reformasi yang ada di Arsip UGM;

3. Menyediakan sumber informasi berbasis arsip dari khazanah arsip statis Arsip UGM (guide tematis tentang reformasi).

\section{Metodologi}

Objek penelitian ini adalah UGM baik secara kelembagaan maupun pribadi sivitas akademika UGM. Fokus penelitian ingin menganalisis tentang keterlibatan UGM dalam gerakan reformasi yang terjadi di Indonesia. 
Penelitian ini merupakan penelitian sejarah yaitu menyajikan pembahasan tentang peristiwa atau fenomena sosial yang melibatkan manusia yang hanya terjadi satu kali. (Kanumoyoso, 2017:5). Metode penelitian ini menggunakan metode sejarah dengan tahapan penentuan tema sejarah, pencarian sumber, kritik sumber, interpretasi, dan historiografi/penulisan sejarah (Kanumoyoso, 2017:5-44). Sumber untuk penelitian ini menggunakan sumber asli dan sumber primer berupa khazanah arsip statis yang ada di Arsip UGM, serta bahan pustaka yang relevan. Kritik sumber dilakukan secara ekstern dengan mengumpulkan data dari beberapa sumber seperti dari arsip tekstual, arsip foto, dan pemberitaan media. Kritik sumber intern tidak dilakukan karena sumber-sumber yang digunakan dalam penelitian ini adalah khazanah arsip statis Arsip UGM (lembaga kearsipan perguruan tinggi di lingkungan UGM) sehingga telah terjamin otentisitasnya.

Penelitian ini membatasi pencarian sumber sejarah/heuristik pada sumber asli dan sumber primer hanya dari khazanah arsip statis Arsip UGM. Limitasi penelitian ini akan berakibat penyajian penulisan sejarah kurang lengkap dan komprehensif karena hanya ditulis bedasarkan sumber sejarah yang ada di Arsip UGM. Namun demikian, hal ini dilakukan dengan maksud khusus yaitu ingin menyajikan kajian sejarah yang sekaligus dapat menjadi guide tematis Arsip UGM tentang reformasi.

\section{Kerangka Pemikiran}

Mempelajari masa lalu bisa menjadi proses pembelajaran. Sejarah akan lebih efektif sebagi proses pembelajaran apabila tidak hanya sekedar dibaca tetapi dikaji dan diteliti (Kanumoyoso, 2017:5). “Tanpa kombinasi sejarah dan teori kita tidak mungkin bisa memahami masa lalu maupun masa kini.” (Burke, 2003:27). Oleh Karena itu, sejarawan dan teori sosial saling melengkapi, seperti yang dilakukan antropologiwan sosial, terutama Clifford Geertz dan Marshall Sahlins, yang memasukkan dimensi sejarah dalam kajian-kajiannya (Burke, 2003:25). Hal yang mendasari hubungan sejarah dengan teori sosial adalah cepatnya perubahan sosial sehingga yang mereka kaji adalah tentang perubahan dari waktu ke waktu dengan kata lain mengkaji sejarah (Burke, 2003:26-27). Sejarah tidak hanya sekedar menyajikan fakta-fakta sejarah tetapi juga memberikan makna atas fakta tersebut. Tidak ada sejarah yang dapat diinterpretasikan tanpa teori dan keyakinan metodologik implisit yang berkaitan satu sama lain yang memungkinkan untuk melakukan seleksi, evaluasi, dan bersikap kritis. (Thomas Khun dalam Maliki, 2012:17). Teori gerakan sosial yang dibawa oleh Habermas memberikan perspektif baru yang lebih luas karena menjelaskan asal gerakan ini dan dampak struktural yang akan ditimbulkan. (Agger, 2012: 356357).

Gerakan reformasi yang digulirkan oleh kekuatan massa hingga membawa perubahan besar bagi Bangsa Indonesia merupakan gerakan sosial. Gerakan sosial (social movement) dalam Kamus Istilah Politik (Muhaimin, dkk. 1985:77) merupakan tindakan atau perbuatan terencana dengan beberapa derajat kesinambungan yang dilakukan oleh suatu kelompok secara teroganisir, dipersatukan oleh tujuan yang sedikit banyak terbatas, disertai program yang terencana dan ditujukan pada suatu perubahan atau sebagai perlawanan. Reformasi diartikan sebagai perbaikan terhadap suatu kesalahan, ketidakefisienan atau sesuatu yang tidak diinginkan secara perlahan-lahan, untuk menciptakan moral, kebiasaan, atau metode yang lebih baik (Muhaimin, dkk. 1985:228). 
Peristiwa gerakan reformasi yang terjadi di Indonesia dan berhasil menumbangkan orde barru merupakan bagian dari sejarah perjalanan Bangsa Indonesia. Peristiwa tersebut telah membawa perubahan besar dalam kehidupan berbangsa dan bernegara kita. Peristiwa ini menjadi pembelajaran penting dalam proses pendewasaan bangsa. Bangsa yang besar adalah bangsa yang menghargai sejarahnya. Meneliti dan mengkaji peristiwa reformasi menjadi salah satu upaya proses pebelajaran tersebut. Pengkajian sejarah reformasi dapat memanfaatkan sumbersumber sejarah berupa arsip.

Pengungkapan dan penulisan sejarah tidak lepas dari peran serta para sejarawan. Kegiatan dilakukan melalui proyek-proyek penulisan sejarah militer, sejarah popular, sejarah lisan, dan sebagainya. Usaha lainnya yang berkontribusi dalam mengungkap sejarah adalah penerbitan arsip yang dilakukan oleh Arsip Nasional Republik Indonesia. Upaya pemanfaatan arsip untuk mengungkap sejarah telah dilakukan tetapi masih banyak sebenarnya informasi sejarah yang tersimpan dalam arsip tetapi belum diketahui dan diungkap oleh khalayak. Oleh karena itu, perlu adanya sinergi antara lembaga pengelola sumber informasi (lembaga kearsipan) dengan para sejarawan untuk membentuk jaringan informasi penulisan sejarah serta tukar menukar informasi (Kuntowijoyo, 1994).

Arsip, khususnya arsip statis, memiliki nilai guna sekunder yang mengandung nilai sejarah. Nilai tersebut meliputi:

1. Nilai evidential yaitu nilai guna yang menunjukkan keberadaan suatu organisasi atau lembaga serta bukti prestasi intelektual.

2. Nilai informasional yaitu informasi yang menunjukkan/membuktikan adanya suatu peristiwa bersejarah.

3. Nilai intrinsik yaitu nilai yang melekat (inherent) pada fisik arsip.
Lembaga kearsipan yang meliputi lembaga kearsipan pusat, lembaga kearsipan propinsi, lembaga kearsipan kabupaten/kota, dan lembaga kearsipan perguruan tinggi merupakan lembaga resmi pemerintah yang bertanggung jawab mengelola arsip-arsip statis sebagai sumber sejarah. Lembaga kearsipan ini tidak hanya mengolah dan menyimpan arsip, tetapi juga harus mengembangkan program pemanfaatan dan pendayagunaan arsip untuk layanan publik (UU No. 43 Tahun 2009). Lembaga kearsipan berfungsi juga sebagai pusat informasi berbasis arsip. Pusat informasi menurut Simpson (Laksmi, dkk., 2011:70) adalah lembaga yang didirikan dengan tujuan menyediakan data-data dan informasi yang terseleksi. Tujuan didirikannya pusat infomasi menurut Evans (Laksmi, dll., 2011:70) adalah sebagai lembaga yang membantu transfer informasi dan perkembangan pengetahuan. Pusat informasi tidak hanya menangani dokumen saja tetapi juga data dan informasi di dalamnya. Artinya, tugas dan tanggung jawab tidak hanya pada penataan fisik semata tetapi juga pengolahan dan penyajian isi informasinya (Weisman dalam Laksmi, dkk., 2011:71).

\section{PEMBAHASAN}

UGM menyatakan dirinya sebagai Universitas terbesar di Indonesia sehingga merasa terpanggil untuk selalu tampil ketika menyaksikan peliknya berbagai persoalan Bangsa Indonesia. Hal ini telah menjadi tradisi yang terus dikembangkan oleh UGM. Dua dasawarsa setelah kemerdekaan Indonesia terjadi persoalan adanya usaha-usaha untuk menggantikan Pancasila yang ada di dalam Pembukaan UUD 1945 sebagai dasar negara. UGM melalui pakarnya, Prof. Mr. Notonagoro, mengeluarkan karya monumental hasil penelitian yang meyatakan bahwa 
Pembukaan UUD 1945 memenuhi syarat sebagai taadsfundamental norm. Karya Prof. Mr. Notonagoro tersebut kemudian menjadi landasan berpijak bagi kehidupan berbangsa dan bernegara (Siaran Pers UGM 23 September 2003).

Peran UGM dalam upaya menangani krisis kehidupan berbangsa dan bernegara kembali ditunjukkan ketika Indonesia mengalami krisis kepercayaan terhadap pimpinan Orde Baru. Masalah ini disusul dengan krisis ekonomi tak berkesudahan yang akhirnya menuntut reformasi di segala bidang pada tahun 1998. Menghadapi hal ini UGM kembali tampil menyuarakan aspirasi rakyat dengan reformasi damai. UGM mendukung empat hal yang menjadi tuntutan reformasi. Pertama, amandemen UUD 1945 yang dianggap memberikan powerful presidency. Kedua, penegakan hukum yang diwujudkan dalam membasmi korupsi, kolusi, dan nepotisme (KKN). Ketiga, demokratisasi yang diejawantahkan dengan mencabut paket 5 undangundang politik. Keempat, penghapusan dwi fungsi ABRI (Siaran Pers UGM 23 September 2003). UGM merupakan sebuah institusi besar yang didalamnya terdiri dari berbagai elemen. Keterlibatan UGM dalam gerakan reformasi tentu melibatkan elemen-elemen yang ada di UGM tersebut.

\section{Dosen}

Sivitas akademika UGM khususnya dosen secara pribadi banyak terlibat dalam gerakan reformasi ini. Salah satu bentuk keterlibatan para dosen ini adalah menjadi Tim Nasional Reformasi Menuju Masyarakat Madani. Pembentukan tim tersebut berdasarkan Keputusan Presiden RI No. 198 Tahun 1998 tertanggal 7 Desember 1998 tentang Pembentukan Tim Nasional Reformasi Menuju Masyarakat Madani. Dasar pertimbangan pembentukan tim ini adalah perkembangan arus reformasi terus meluas ke berbagai aspek kehidupan bangsa dan negara. Hal ini membawa dampak yag sangat besar terhadap kehidupan ekonomi, politik, hukum, sosial, dan budaya Bangsa Indonesia. Oleh karena itu, perlu dibentuk tim yang bertugas merumuskan rekomendasi kebijaksanaan antisipatif untuk mempersiapkan berbagai aspek kehidupan bangsa dan negara. Tim ini terdiri dari Dewan Penasehat, Tim Pelaksana, Kelompok Reformasi Ekonomi, Kelompok Reformasi Teknoindustri, Kelompok Reformasi Politik, Kelompok Reformasi Kelembagaan, Kelompok Reformasi Sosial Budaya, dan Kelompok Reformasi Hukum dan Perundang-undangan.

Tim ini disebut sebagai Tim Nasional berada di bawah dan bertanggung jawab langsung kepada presiden. Tugas pokok tim ini adalah:

1. Menghimpun pemikiran tentang transformasi ekonomi, politik, hukum, sosial dan budaya serta perkiraan dampak globaliasi terhadap berbagai aspek kehidupan bangsa;

2. Melakukan telaah dan kajian perkembangan global jangka menengah dan jangka panjang dalam bidang ekonomi, politik, hukum, sosial budaya serta berbagai peluang dan dampak terhadap kepentingan nasional;

3. Menyusun makalah (konsepsi) kebijaksanaan (policy papers) tentang perkiraan arah perkembangan transformasi tersebut untuk disampaikan kepada presiden; dan

4. Merumuskan rekomendasi serta pemikiran tentang upaya untuk mendorong transformasi menuju masyarakat madani.

Tim ini beranggotakan tokohtokoh yang berintegritas dari berbagai bidang. Sivitas akademika UGM yang masuk dalam tim tersebut adalah:

1. Sofian Effendi sebagai Wakil Ketua Tim Pelaksana 
2. M. Dawam Rahardjo sebagai Koordinator Kelompok Reformasi Ekonomi

3. Bambang Sudibyo sebagai Anggota Kelompok Reformasi Ekonomi

4. Ichlasul Amal sebagai Anggota Kelompok Reformasi Politik

5. Agus Dwiyanto sebagai Anggota Kelompok Reformasi Kelembagaan

6. Sjafri Sairin sebagai Anggota Kelompok Reformasi Sosial Budaya

7. Erman Rajagukguk sebagai Anggota Kelompok Reformasi Hukum dan Perundang-undangan.

Hasil kerja dari Tim Nasional tersebut dapat ditelusur dari khazanah arsip statis yang tersimpan di Arsip UGM adalah:

1. Kelompok Reformasi Politik yang dikoordinatori oleh Susilo Bambang Yudhoyono telah melakukan pertemuan pada hari Jumat tanggal 5 Februari 1999 di Jakarta. Pertemuan untuk konsolidasi tim dengan membahas tentang pemahaman tugas Kelompok Reformasi Politik dilanjutkan dengan curah pendapat. Pertemuan tersebut merumuskan:

a. Tiga hal pokok yang menjadi perhatian utama Kelompok Reformasi Politik adalah:

1) Bagaimana Indonesia yang baru akan diwujudkan dari dimensi politik?

2) Paradigma apa yang akan digunakan dalam transformasi politik menuju masyarakat madani?

3) Analisa perkiraan strategis dari kebijakan, strategi, dan langkah-langkah yang akan ditempuh.

b. Hasil pembahasan agenda akan dituangkan dalam policy paper yang akan disampaikan pada Presiden tanggal 26 Februari 1999.

Policy Paper yang berhasil disusun oleh Kelompok Reformasi Politik diberi judul "Mengaktualkan Cita-Cita
Republik: Reformasi Politik Menuju Masyarakat Madani”. Paper ini memberikan rekomendasi berupa:

1) Perlu peningkatan etika dan tata karma politik yang menghargai nilai-nilai kesetaraan serta ketaatan azas;

2) Kesadaran elite dan massa terhadap arti pentingnya aturan main dan supremasi hukum harus dilembagakan;

3) Pendidikan kesadaran berbangsa dan bernegara bukan hanya ditujukan kepada massa, tetapi lebih ditujukan kepada elite;

4) Manajemen diharapkan cukup lentur disesuaikan dengan kondisi sosio-kultural dan sosio-historis masyarakat Indonesia demi menjamin proses perubahan secara bertahap dan damai;

5) Perlu langkah konkrit dalam membangun rasa percaya diri sebagai bangsa;

6) Mendorong media massa untuk terus meningkatkan profesionalismenya;

7) Perlu penerapan secara konsisten paradigm baru peran sosial politik ABRI demi membangun simpati publik terhadap pentingnya pengembangan profesionalisme TNI.

8) Proses dialog hendaknya menjadi acuan semua pihak, baik intraelite maupun antara elite dan massa.

2. Kelompok Reformasi Hukum dan Perundang-undangan

Salah satu anggota kelompok ini adalah Albert Hasibuan (Alumni UGM). Salah satu hasil kajian tim ini adalah mengajukan amandemen UUD 1945 dan pengisian jabatan presiden melalui pemilihan langsung. Hasil kajian dan 
rekomendasi ini disampaikan di hadapan Pimpinan dan Anggota Dewan Pertimbangan Agung RI pada tanggal 15 Juni 1999 di Jakarta. Hasil kajian amandemen UUD 1945 di antaranya berisi lima penyebab ketidakberhasilan UUD 1945, beberapa kekosongan dalam UUD 1945, tata cara pembaharuannya, materi pembaharuan UUD 1945, dan pengembangan konsepsi UUD 1945. Materi kedua yaitu tentang usulan gagasan pemilihan presiden melalui pemilihan langsung dijabarkan melalui landasan dan pokok pikiran pengisian jabatan presiden melalui pemilihan langsung dan implikasi pengisian jabatan presiden melalui pemilihan langsung terhadap UUD 1945 (Bahan presentasi Kelompok Reformasi Hukum dan Perundangundangan, 1999).

3. Kelompok Reformasi Ekonomi

Kelompok ini diketuai oleh $\mathrm{M}$. Dawam Rahardjo (UGM). M. Dawam Rahardjo selaku koordinator menyusun naskah akademik berjudul "Mayarakat Madani” sebagai bahan kajian untuk merumuskan usulan dan rekomendasi reformasi di bidang ekonomi. (Berkas reformasi, Rahardjo, tt)

Pada tahun 1999 Presiden BJ Habibie mengeluarkan Kepres No. 18 Tahun 1999 tertanggal 24 Pebruari tentang Perubahan Keputusan Presiden No. 198 Tahun 1998 tentang Pembentukan Tim Nasional Reformasi Menuju Masyarakat Madani. Kepres ini diterbitkan untuk mengubah dan menyempurnakan susunan tim dalam rangka mengingkatkan efektifitas kinerja tim. Dalam perubahan tim ini, tokohtokoh UGM masih tetap diangkat sebagai tim baik sebagai koordinator maupun anggota.

Prof. Ichlasul Amal bersama dengan 8 tokoh lainnya yaitu Prof. Dr. Emil Salim, Prof. Dr. Moh. Kamil Tadjudin, Prof. Dr. Saparinah Sadli, Prof.
Miriam Budihardjo, Prof. Dr. Nurcholis Madjid, Dr. Todung Mulya Lubis, Dr. Daniel Dhakidae, dan Dr. Akmal Taher; secara bersama-sama mendirikan sebuah yayasan yang bernama Yayasan Reformasi Pemilu yang berkedudukan di Jakarta Pusat Jalan Borobudur No. 8. Terkait dengan proses pendirian yayasan tersebut kemudian 9 tokoh ini pada tanggal 9 September 1999 memberikan kuasa kepada Dra. Smita Notosusanto, MA. untuk menandatangani akte pendirian dan mewakili proses-proses lainnya (Berkas Reformasi 1999).

\section{Kelembagaan: Sumbangan Gagasan}

Kritik, saran, dan masukan kepada pemerintah menjadi salah satu cara UGM untuk mengawal jalannya refomasi. Pada tanggal 14 Maret 2004, UGM mengeluarkan Deklarasi Dialog Kebangsaan: Program Aksi Meluruskan Aksi Reformasi. Deklarasi ini berisi sumbang saran dan kritik UGM dan para alumni yang terpanggil untuk mengawal perjalanan bangsa dalam pelaksanaan reformasi. UGM dan para alumni memandang telah terjadi kelambanan dan ketidakjelasan arah reformasi. Oleh karena itu, UGM menawarkan konsep yang dapat digunakan sebagai pegangan dalam merumuskan program aksi reformasi. Enam poin yang dapat dijadikan pegangan tersebut adalah sebagai berikut:

1. Reformasi tetap berpijak pada semangat percaya diri dan semangat kebangsaan Indonesia berdasarkan Pancasila.

2. Reformasi ekonomi, sosial, dan budaya merupakan keniscayaan yang harus ditempuh melalui aktualisasi kepemimpinan bangsa yang hanya dapat dihasilkan melalui pemilu yang jujur, adil, dan bersih. UGM dan alumni menghimbau segenap unsur bangsa untuk menjaga agar pemilu berjalan jujur, adil, dan bersih. 
3. Presiden terpilih dalam menjalankan tugasnya harus mengemban amanat untuk melaksanakan programprogram aksi reformasi yang dilandasi dengan semangat kebangsaan dan disiapkan dengan partisipasi seluruh komponen bangsa.

4. Pengembangan pendidikan harus berpilar pada pengembangan harga diri dan komitmen terhadap nilai-nilai kebangsaan. Pengembangan ilmu pengetahuan dan teknologi harus membumi dan mengakar pada kepentingan bangsa.

5. Pemberantasan korupsi, kolusi, dan nepotisme (KKN) menjadi prasarat mutlak bagi keberlanjutan reformasi. Perlu adanya keteladanan pemimpin bangsa di setiap lapisan yang didukung gerakan moral anti KKN.

6. Reformasi menuntut penguatan jati diri dan moral bangsa dengan penataan ulang kelembagaan dan hukum yang berkeadilan.

(Deklarasi Dialog Kebudayaan: Program Aksi Meluruskan Reformasi, 2004)

Tahun 2004, UGM menyusun konsep sebagai masukan kepada Presiden RI dalam rangka mengawal jalannya reformasi. Masukan tersebut disusun dalam sebuah buku dengan judul "Curah Gagas Masyarakat Kampus: Rekomendasi untuk Presiden”. Buku ini berisi masukan-masukan untuk Presiden RI di bidang sosial budaya, hukum, politik dan pemerintahan, ketahanan bangsa, pendidikan, ekonomi, riset dan tekno-industri, dan hubungan luar negeri. Buku ini disunting oleh sebuah tim yang terdiri dari Sofian Effendi, Marwan Asri, Marsudi Triatmodjo, Purwo Santoso, Siggih Hawibowo, Suryo Baskoro, Supra Wimbarti, Eddy O.S. Hiariej, Armaidy Armawi, Nizam, fahmi Rady, dan Siti Muti'ah Setyawati (Effendi, 2004).

Dosen-dosen di lingkungan Fakultas Ilmu Sosial dan Ilmu Politik menuangkan ide dan gagasan serta kritikkritik sosial politik dalam bentuk tulisan.
Kumpulan tulisan-tulisan tersebut di antaranya dibukukan dengan judul “Kampus Biru Menggugah”. Buku ini diterbitkan oleh Kafisipolgama pada tahun 2004. Beberapa tema kritik dan gagasan yang terangkum dalam buku tersebut di antaranya tentang demoralisasi bangsa dalam perspektif media, jabatan presiden, demokrasi pelayanan publik, reformasi birokrasi, korupsi, partai politik, desentralisasi keuangan daerah, otonomi daerah, terorisme, dan hubungan internasional (Bandoro dkk., 2004).

\section{Kelembagaan: Pernyataan Sikap}

UGM secara kelembagaan telah beberapa kali menyampaikan pernyataan sikap UGM dalam menghadapi kondisi Bangsa Indonesia saat reformasi bergulir. Tanggal 13 Mei 1998, sebelum terjadi tragedi aksi demonstrasi tanggal 18 Mei yang menimbulkan jatuh korban, UGM mengeluarkan pernyataan sikap. Pernyataan ini disampaikan oleh sebuah forum yang bernama "Forum Komunikasi Akademisi UGM”. Melihat kondisi krisis bangsa yang semakin larut dan berharap korban rakyat dapat diatasi, forum ini dengan memohon rida dan rahmat Allah mengajukan 4 sikap sebagai berikut:

1. Menuntut pengunduran diri Presiden Soeharto;

2. Mendorong dan mendukung segala upaya pembentukan lembaga nasional yang independen dalam rangka pegantian kepemimpinana nasional yang aman dan damai;

3. Mendukung sepenuhnya gerakan reformasi yang dilakukan oleh mahasiswa dan mengutuk segala bentuk kekerasan;

4. Menghimbau seluruh masyarakat agar tidak melakukan pengrusakan/tindakan anarkis. (Pernyataan Sikap Forum Komunikasi Akademisi UGM, 1998). 
Forum Komunikasi Akademisi UGM pada tanggal 18 Mei 1998 kembali membuat curah gagasan yang berjudul "Tidak Ada Reformasi Tanpa Perubahan Kepemimpinan Nasional”. Curah gagasan berupa tulisan 2 lembar halaman ini berisi beberapa sikap dan gagasan. Forum ini menyatakan memberikan penghormatan pada bendera setengah tiang, bukan sebagai hari berkabung nasional atau simbol permulaan kesedihan dan duka nestapa Bangsa Indonesia. Penghormatan bendera setengah tiang dimaksudkan oleh Forum Komunikasi Akademisi UGM, pertama sebagai bentuk ingin merasakan bahwa kesedihan ibu pertiwi telah sampai pada titik nadirnya dan bendera setengah tiang yang dikibarkan pada tanggal 18 Mei 1998 merupakan pertanda akan batasbatas kesabaran yang perlu ditoleransi. Kedua, bendera setengah tiang diartikan sebagai simbol semangat dan vitalitas bagi mahasiswa dalam perjuangan mereka untuk reformasi dan perubahan yang lebih hakiki. Penghormatan bendera setengah tiang bukan hanya ingin menyatakan bahwa para akademisi UGM bersama dengan para mahasiswa yang tengah berjuang untuk perubahan dan reformasi, tetapi juga mendorong para mahasiswa agar mereka tidak surut semangatnya sampai cita-cita reformasi tercapai. Namun demikian, akademisi UGM juga ingin mengingatkan gerakan perjuangan mahasiswa harus dilandasi prinsip perjuangan tanpa kebencian dan kekerasan, sebab dua prinsip itulah yang akan menjamin bahwa perjuangan mereka bernilai secara moral, anggun, dan suci. Ada dua hal yang harus direnungkan dengan sungguh-sungguh. Pertama, sangat penting untuk memahami paham mahasiswa yang menuntut reformasi total dan radikal akibat ketidakpercayaan pada kepemimpinan nasional sehingga menuntut adanya pergantian kepemimpinan nasional. Kedua, sikap mahasiswa ini meskipun tidak popular di mata penguasa, tetapi tetap tidak masalah karena akademisi UGM bekerja bukan semata-mata untuk kekuasaan atau untuk memperoleh keuntungan dari kekuasaan. Justru yang harus dilakukan adalah saling mengingatkan untuk selalu memilih sikap tanpa pamrih, ikhlas, dan tidak mengharapkan apapun dari hasil perjuangan reformasi ini kecuali peningkatan matabat dan kesejahteraan seluruh rakyat. Sikap dan gagasan ini dibuat oleh Forum Komunikasi Akademisi UGM sebagai bentuk aksi keprihatinan yang dilakukan di Bulaksumur tanggal 18 Mei 1998 (Forum Komunikasi Akademisi UGM, 1998).

UGM secara resmi kelembagaan melalui Rektor UGM pada tanggal 19 Mei 1998 mengeluarkan pernyataan sikap dalam menyikapi krisis nasional yang mengancap persatuan dan kesatuan Bangsa Indonesia. Isi pernyataan sikap UGM tersebut adalah, pertama mendesak Presiden Soehato mengundurkan diri dari jabatannya dalam tempo yang sesingkatsingkatnya. Kedua, mendesak segera dibentuk Presidium Pimpinan nasional. Ketiga, menyerukan kepada mahasiswa dan seluruh elemen bangsa untuk bekerjasama mewujudkan reformasi total. Pernyataan tersebut dibuat sebagai bentuk pengungkapan pertanggungjawaban moral dan sejarah UGM kepada Bangsa dan Negara RI (Pernyataan UGM 1998).

Pernyataan sikap sebagai bentuk pertanggungjawaban moral menghadapi kondisi kritis saat itu juga dilakukan oleh fakultas di UGM. Sivitas akademika Fakultas Geografi UGM pada tanggal 19 Mei 1998 melayangkan surat kepada Sri Sultan HB X yang intinya memohon Sultan HB $X$ membuat pernyataan Yogyakarta siap menjadi Ibu Kota Republik Indonesia dan menyiapkan segala persiapannya. Hal ini didasari atas keprihatinan kondisi Jakarta yang tidak kondusif sehingga para pemimpin sulit untuk berfikir jernih dan konstitusional. Yogyakarta dinilai sebagai tempat yang 


\begin{abstract}
tepat untuk memindahkan pusat pemerintahan Indonesia karena Yogyakarta berhati nyaman pehuh dengan gelora reformasi damai. Yogyakarta memiliki nurani terbukti para pemimpinnya arif, memiliki kaum terpelajar dan pemikir kritis, dan masyarakatnya berbudaya. Yogyakarta kota kerakyatan karena bersatunya Sri Sultan HB X dengan rakyat Yogyakarta dapat mengayomi dan melayani para pemimpin untuk berunding dan menjernihkan nurani sehingga dapat merumuskan rencana baru Indonesia dalam mengatasi krisis multidimensi. Permohonan ini dilakukan dengan mengingat sejarah masa lalu yang telah membuktikan bahwa Yogyakarta telah menyelamatkan Indonesia pada saat krisis perjuangan tahun 1946 - 1949 dengan menjadi Ibu Kota RI (Surat Sivitas Akademika Fakultas Geografi UGM, 1998).
\end{abstract}




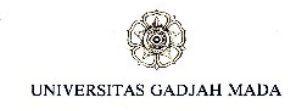

PernyataAn Universitas gadjah MADA

Menginge: cinamika perkentançan krisis nassonal yang sudah mengancam

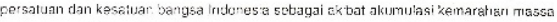
torhadlap praktekk-praktck kchidjpan ketatanegaraan yarng bertentangan dengan

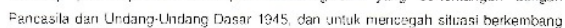

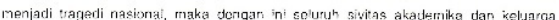
a'unni Lniversitas Gasdiat, Macta menryatak an

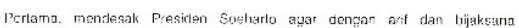

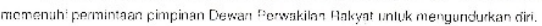

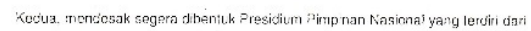

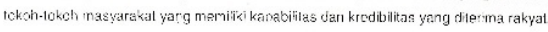

Ket ga. manyerukan kepada mahtusissa tan soluruh elemen bangsa lainnya

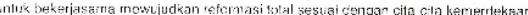

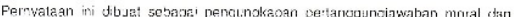
sejarah Universitas Garjalh Mada kenacia barngsa dan noçarn Republik Indonesia.

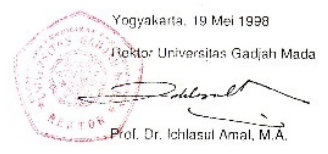

Gambar 1. Surat Pernyataan Sikap UGM dalam Reformasi

Sumber: Khazanah Arsip Statis Arsip UGM
CIVITAS AKADEMIKA IAKLLTAS GEOGRAFI UNIVERSITAS GAD.JAH MADA

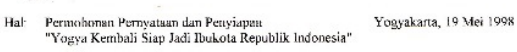
Keppuda Yth.

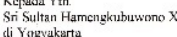

Denewer horrote

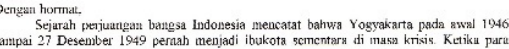

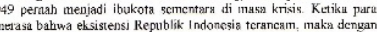

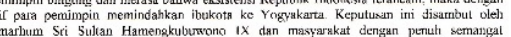

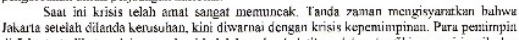

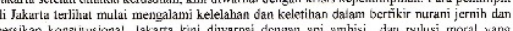

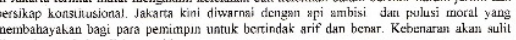
iternukan pada kondisis seperti ith

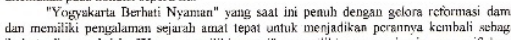

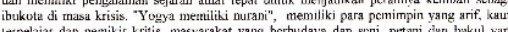

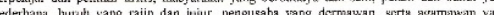

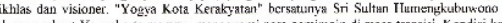

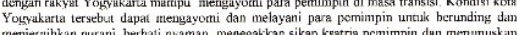

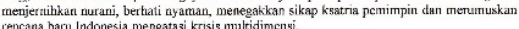

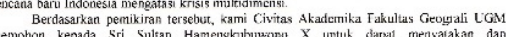

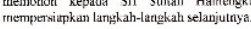
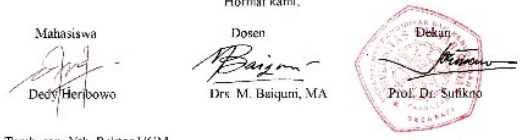

Tembusan. Yth. Rektor UGM

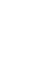




\section{Forum-Forum Ilmiah}

Tradisi ilmiah turut mewarnai gerakan reformasi di UGM. Banyak forum-forum ilmiah diselenggarakan untuk membahas, mengkaji, dan merumuskan jalannya reformasi. Beberapa forum ilmiah yang diselenggarakan di antaranya, tanggal 27 - 28 Januari 1999. UGM menyelenggarakan semiloka dengan tema "Refleksi Kritis terhadap Proses Reformasi”. Semiloka ini mengkritisi substansi reformasi dari berbagai bidang seperti globalisasi dan pembangunan ekonomi disampaikan T. Jacob, bidang ekonomi disampaikan Anggito Abimanyu, bidang hukum disampaikan Moh. Mahfud MD, refleksi reformasi multi dimensional disampaikan Ichlasul Amal, refleksi kritis jalannya reformasi disampaikan A.M.W. Pranarka, refleksi reformasi dari tinjauan filsafat disampaikan Koento Wibisono Siswomihardjo (Kumpulan Makalah Semiloka Refleksi Kritis terhadap Proses Reformasi, 1999).

Tanggal 25-27 September 2003 bertempat di Ruang Sidang Balai Senat UGM diselenggarakan Seminar Nasional Meluruskan Jalan Reformasi. Seminar ini diikuti oleh 300 peserta dari akademisi, tokoh masyarakat, mahasiswa, wakil Kagama, ketua partai politik, LSM, pers, dan berbagai institusi yang relevan. Seminar ini mengusung tema meluruskan jalan reformasi dari perspektif ideologi, moral dan pendidikan; sosial dan budaya; ekonomi; kebijakan sains dan teknologi untuk mendukung industri nasional; hukum, HAM dan demokrasi; dan good governance (Siaran Pers UGM 23 September 2003).

UGM menyelenggarakan Dialog Kebangsaan Program Aksi Meluruskan Reformasi pada tanggal 11 - 14 Maret 2004 di UGM yang dihadiri oleh 150 orang akademisi, alumni, dan praktisi. Dialog ini membahas hal-hal yang menjadi permasalahan krusial dalam mengawal jalannya reformasi. Dialog ini terdiri dari 5 komisi yaitu Komisi 1: Sosial Budaya, diketuai Sjafri Sairin, Komisi 2: Pendidikan, diketuai oleh Kunto Wibisono, Komisi 3: Hukum yang Berkeadilan, diketuai Koesnadi Hardjasoemantri, Komisi 4: Ekonomi, diketuai oleh Mubyarto, Komisi 5: Pemerintahan, diketuai oleh Agus Dwiyanto, Komisi 6: Politik dan Hubungan Luar Negeri, diketuai oleh Sumaryo Suryokusumo, Komisi 7: Keamanan, diketuai Yahya Muhaimin.

Berbagai forum ilmiah membahas reformasi yang diselenggarakan merupakan panggilan UGM sebagai bukti pengabdian kepada bangsa. Hal ini disampaikan oleh Rektor UGM dalam sambutan pada acara Dialog Kebangsaan, seperti dikutip berikut ini :

"Mengenai UGM ini, Ir. Soekarno pernah menyatakan "Tanggal 19 Desember 1949 dipilih sebagai hari kelahiran UGM untuk memperlihatkan pada dunia bahwa Bangsa Indonesia adalah bangsa yang kuat. Meskipun telah diserang pada 19 Desember 1948 oleh Belanda tetapi dalam waktu satu tahun kita dapat membangun universitas. Universitas disamping pusat untuk mencerdaskan bangsa namun juga sumber inspirasi perjuangan bangsa”. Amanat tersebut yang menyebutkan bahwa UGM selain sebagai pusat mencerdaskan bangsa tepi juga dituntut untuk menjadi sumber inspirasi bangsa. Seminar Meluruskan Reformasi yang diikuti Dialog Kebangsaan Maret 2004, Konvensi Kampus Mei 2004 dan dialog ini merupakan jawaban apa yang diamanatkan Ir. Soekarno.” (Hardjasoemantri, 2004:98-99).

Forum-forum ilmiah yang membahas dan mengkaji reformasi tidak hanya diselenggarakan oleh UGM, tetapi 
juga oleh unit-unit kerja di lingkungan UGM.

1. P3PK menyelenggarakan Seminar Reformasi Negara Kepolisian atau Revolusi pada tanggal 7 Mei 1998;

2. MAP UGM menyelenggarakan Seminar Reformasi di dalam Administrasi Publik tanggal 16 Mei 1998;

3. Diskusi Panel Suksesi Kepresidenan dan Reformasi Hukum di Indonesia tanggal 28 Mei 1998;

4. Pusat Studi Keamanan dan Perdamaian (PSKP) menyelenggarakan Seminar Internasional tentang Pendidikan Demokrasi dan Dialog Sipil-Militer pada tanggal 11 Juni 1998;

5. Pusat Studi Pancasila menyelenggarakan Diskusi Panel Pancasila dalam Perpektif Gerakan Reformasi tanggal 15 Juni 1998;

6. Pusat Penelitian Pembangunan Pedesaan dan Kawasan UGM tanggal 29-30 Juni 1998 menyelenggarakan Seminar Strategi dan Upaya Penyusunan Agenda Politik dalam Reformasi;

7. PPH Kagama tanggal 8 Juli 1998 menyelenggarakan Seminar Nasional Refleksi atas Pancasila dan UUD 1945 sebagai Dasar dan Arah Reformasi Nasional;

8. Magister Ekonomika Pembangunan (MEP) UGM pada Tanggal 7 Juni 2003 menyelenggarakan seminar nasional di Hotel Hyatt Regency Yogyakarta dengan tema "Reformasi Keuangan Darah: Teori dan Implementasi” .

\section{Gerakan Mahasiswa}

Mahasiswa juga turut aktif dalam gerakan reformasi. Khazanah arsip statis yang ada di Arsip UGM tidak banyak yang menceritakan dan menggambarkan gerakan-gerakan yang dilakukan oleh mahasiswa. Hal ini dapat dipahami karena gerakan mahasiswa ini belum terdokumentasi dengan baik dan arsiparsip bukti peristiwa gerakan reformasi dari kalangan mahasiswa ini belum diakuisisi. Beberapa sumber arsip yang ada khususnya arsip foto, gerakan mahasiswa banyak dilakukan melalui aksi demonstrasi. Mahasiswa tidak hanya melakukan aksi turun ke jalan, tetapi juga terlibat dalam forum-forum ilmiah dan bergabung dengan aksi yang dilakukan oleh sivitas akademika UGM lainnya.

Sebuah buku sejarah yang ditulis dalam memperingati 50 tahun UGM, menyebutkan bahwa gerakan reformasi telah dipelopori oleh mahasiswa UGM sejak Maret 1998 melalui gerakan protes dan demonstrasi yang dilakuan terus menerus. Demonstrasi yang awalnya berskala kecil dan sporadis ini semakin meluas dan mendapat dukungan moral dari seluruh elemen kampus baik dosen maupun pimpinan universitas (Purwanto, dkk., 1999:124). Berdasarkan foto-foto yang ada, mahasiswa UGM telah melakukan aksi demonstrasi menuntut perubahan sejak tahun 1996. Beberapa tuntutan mereka sama dengan agenda reformasi seperti menolak 5 paket UU (1996), dan menolak Soeharto sebagai Presiden RI hasil pemilu 1997 (1997). 


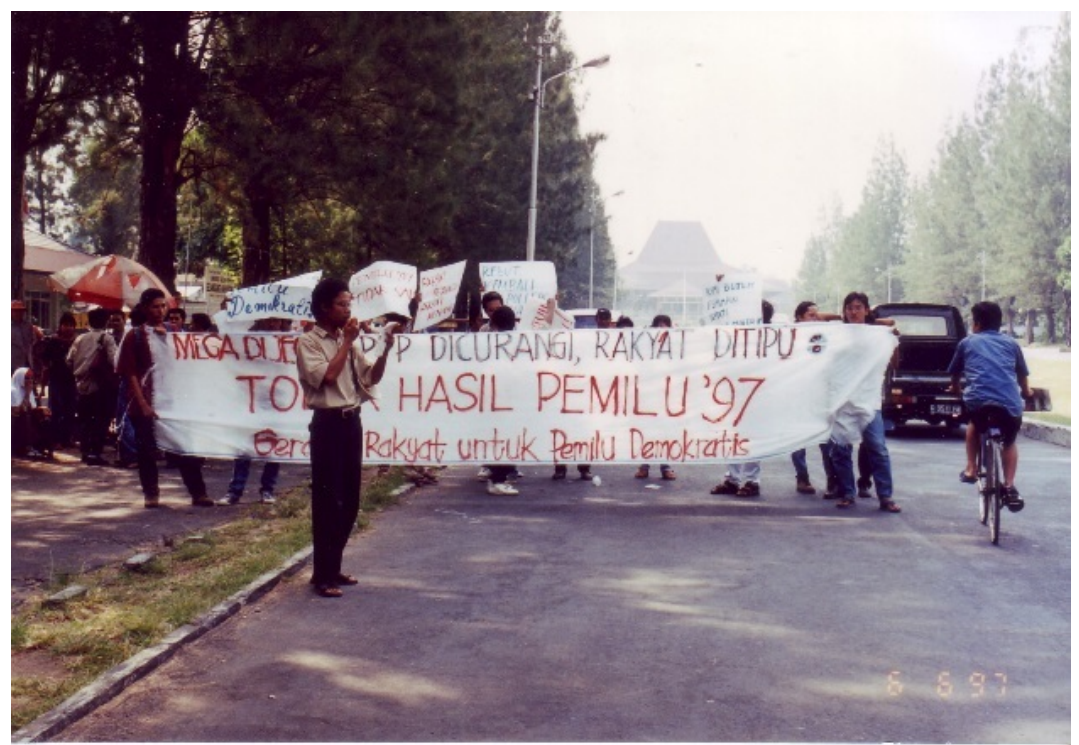

Gambar 2. Demo Mahasiswa UGM Tahun 1996

Sumber: Khazanah Arsip Statis Arsip UGM

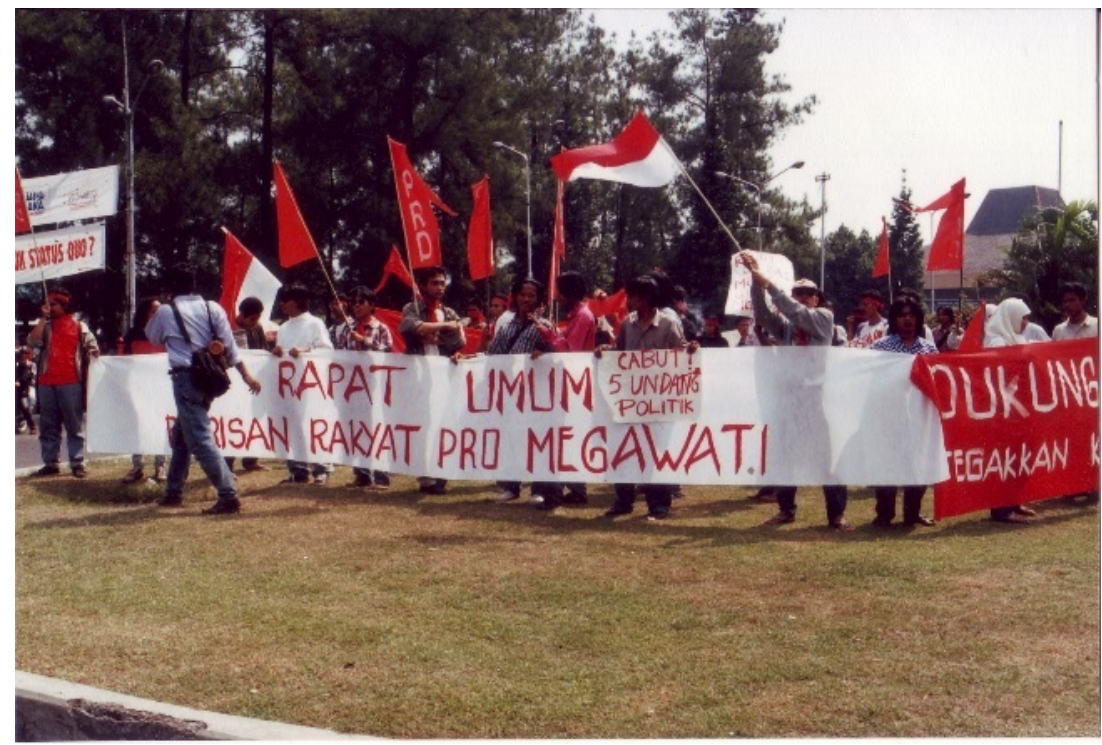

Gambar 3. Demo Mahasiswa UGM Tahun 1997

Sumber: Khazanah Arsip Statis Arsip UGM 
Tanggal 3 dan 4 April aksi demonstrasi ahasiswa berujung bentrok dengan aparat keamanan yang mengakibatkan timbul korban dari pihak mahasiswa. Berbagai bahaya yang mengancam mahasiswa seperti jatuh korban dan penangkapan ratusan mahasiswa tidak meyurutkan laju gerakan mahasiswa. Hampir setiap hari mahasiswa UGM melakukan gerakan reformasi melalui berbagai cara seperti orasi, membangun tenda-tenda keprihatinan, hingga aksi mogok makan. (Purwanto, dkk., 1999:124-125).
Menanggapi semangat gerakan reformasi yang dipelopori oleh mahasiswa ini, UGM secara kelembagaan dalam hal ini diwakili oleh Rektor UGM mendukung gerakan reformasi. Tepat pada tanggal 19 Mei 1998 saat terjadi peristiwa demonstrasi besar-besaran di berbagai kota di antaranya di Yogyakarta, Rektor UGM mengeluarkan seruan dihadapan puluhan wartawan media cetak dan elektronik supaya aksi reformasi dilakukan dengan damai (Warta UGM, Mei 1998). Tanggal 20 Mei 1998 kembali dilakukan demonstrasi aksi reformasi di GSP UGM (sumber arsip foto No. AF4/SC.CR/1998-2H). Aksi-aksi tersebut juga didukung oleh dosen dan pegawai UGM.

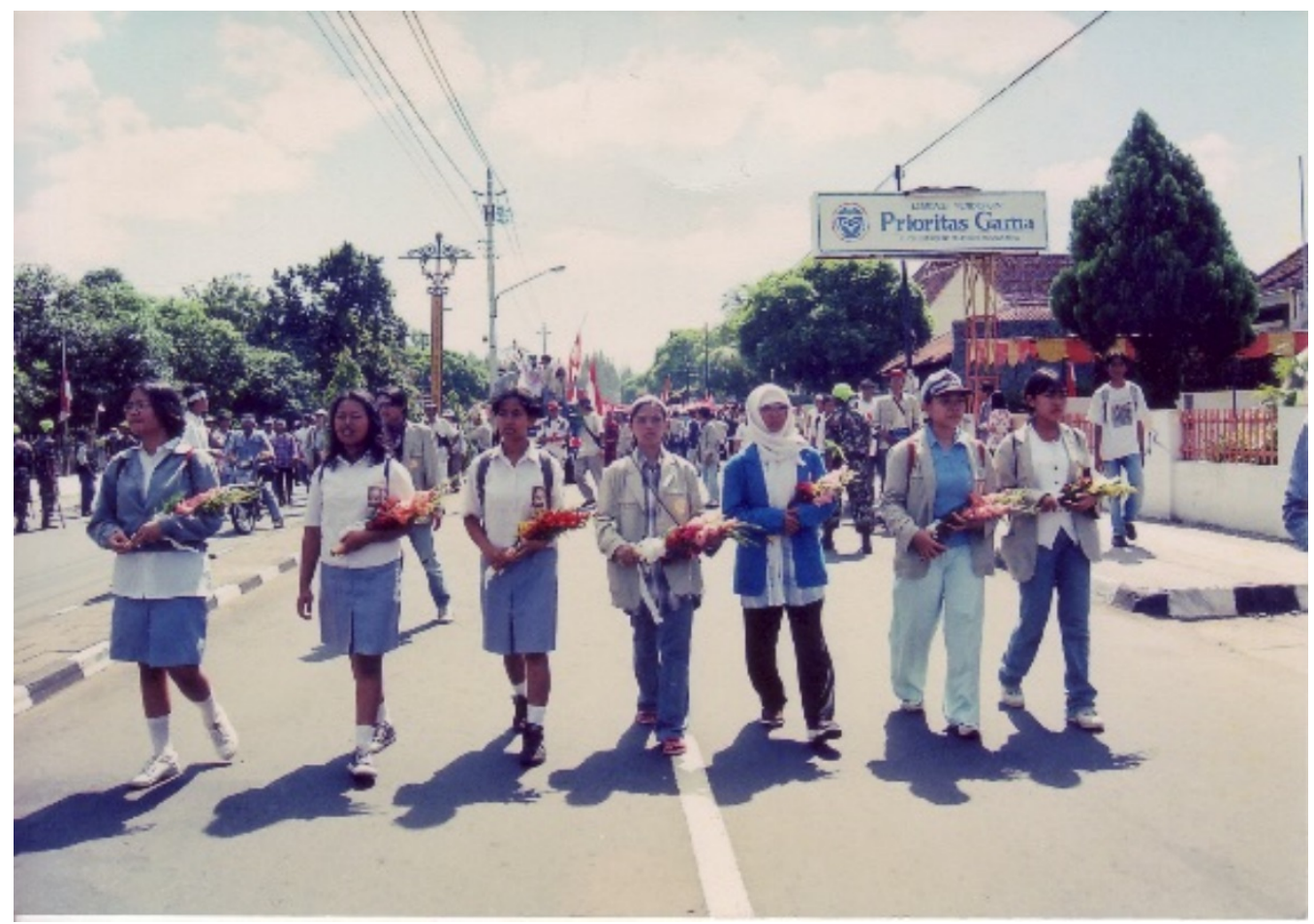

Gambar 4. Mahasiswa UGM dan Pelajar Mengikuti Aksi Tahun 1998 Sumber: Khazanah Arsip Statis Arsip UGM 


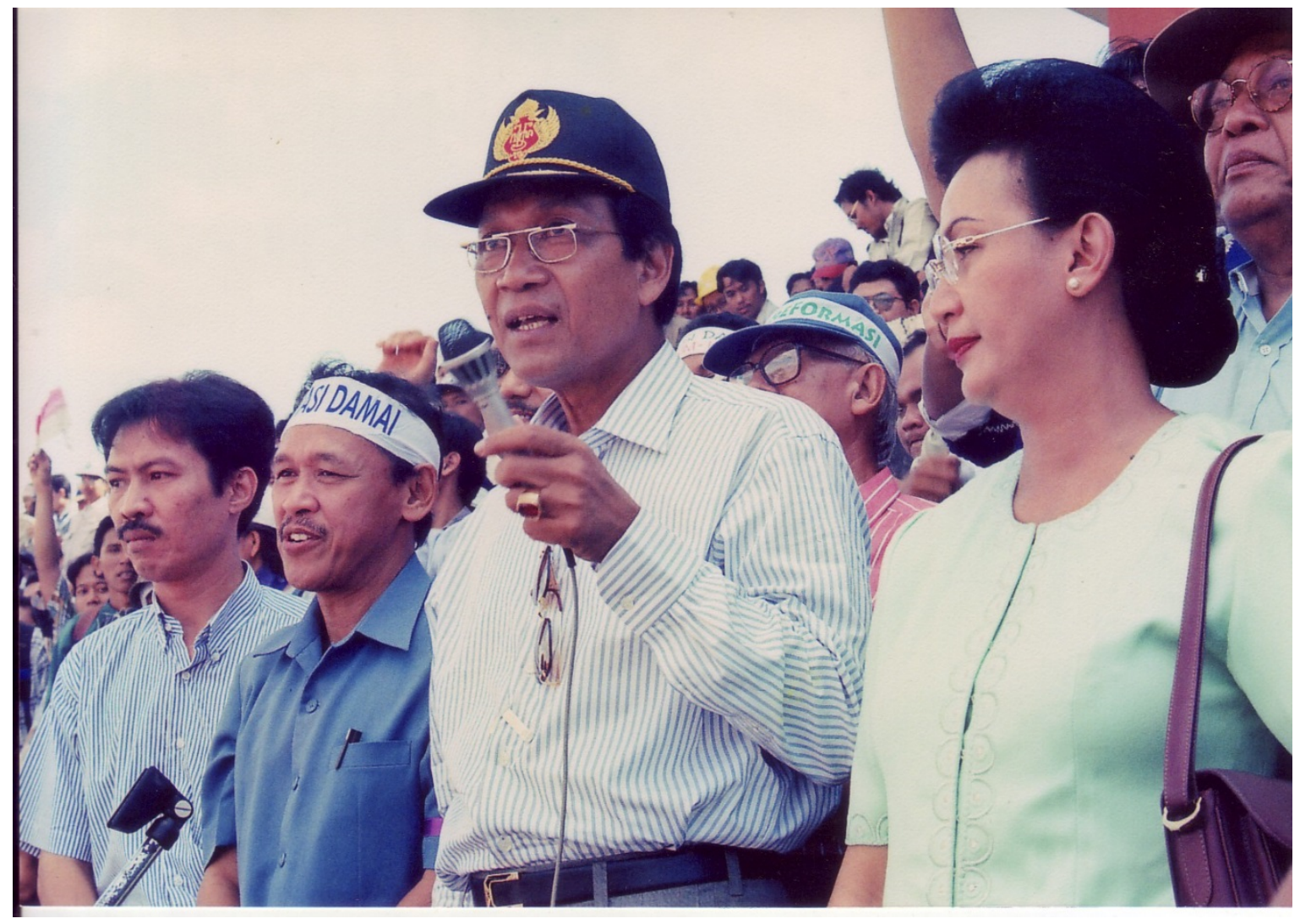

Gambar 5. Sri Sultan Hamengku Buwono X Menyampaikan Orasi dalam Aksi Tahun 1998

Sumber: Khazanah Arsip Statis Arsip UGM 


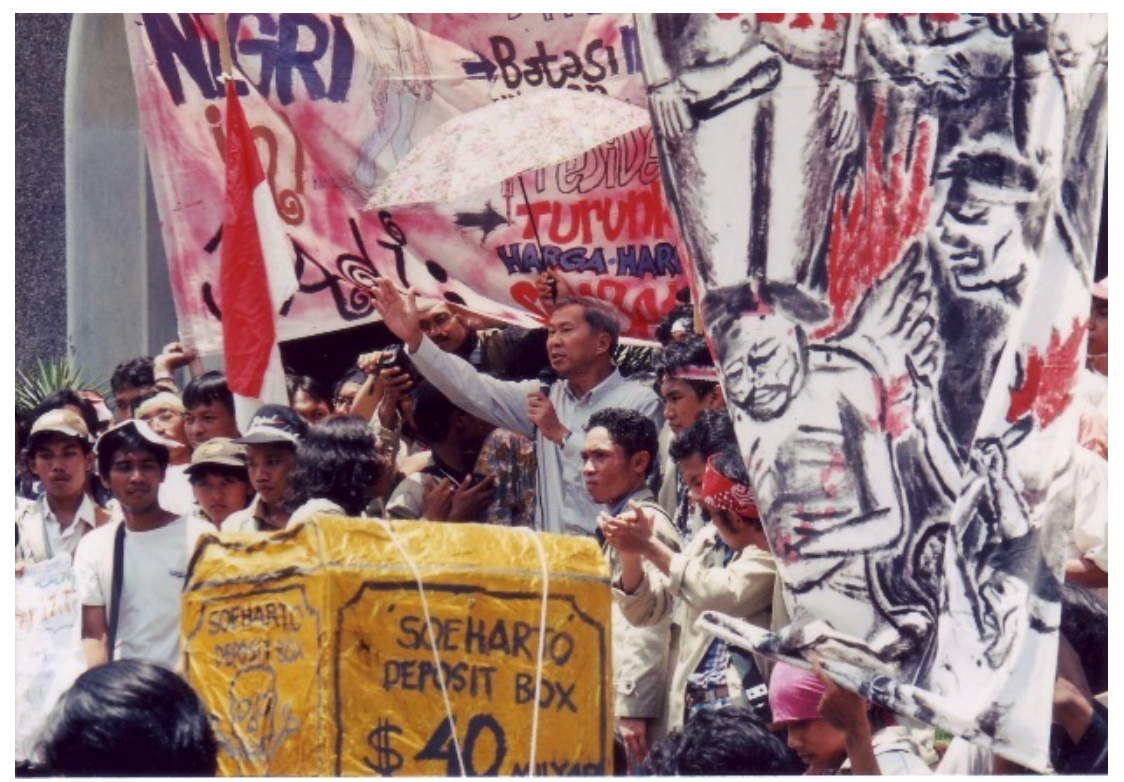

Gambar 6. Dosen UGM Orasi dalam Aksi Tahun 1998 Sumber: Khazanah Arsip Statis Arsip UGM

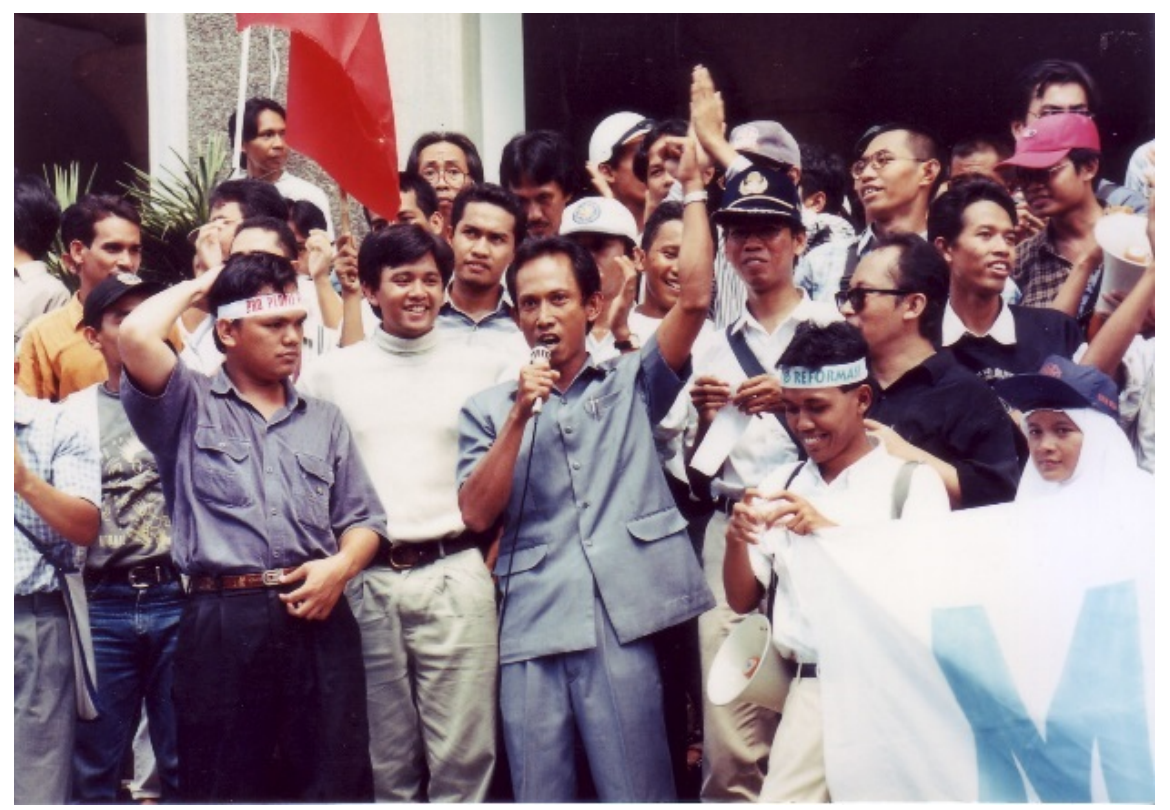

Gambar 7. Pegawai UGM orasi dalam Demo 1998

Sumber: Khazanah Arsip Statis Arsip UGM 
Gerakan ilmiah yang dilakukan mahasiswa UGM di antaranya Subiyantoro, Presiden Mahasiswa UGM Periode 1998/1999, menyampaikan makalah berjudul "Sedikit Saja tentang Reformasi Hukum” dalam dialog dengan peserta SPATI angkatan III di UGM tanggal 31 Oktober 1998. Mahasiswa Fakultas Geografi UGM juga terlibat dan turut serta menyatakan sikap mendorong Sri Sultan HB IX untuk menyatakan sikap Yogyakarta siap menjadi ibu kota RI. Surat sivitas akademika Fakultas Geografi yang dikirimkan ke Sri Sultan HB IX ini ditandatangani oleh perwakilan mahasiswa, perwakilan dosen, dan Dekan Fakultas Geografi UGM.

\section{Pemberitaan Media UGM}

Warta UGM sebagai media komunikasi internal UGM yang diterbitkan oleh Bagian Humas UGM dalam beberapa edisinya memuat berbagai ulasan dan berita tentang reformasi. Warta UGM edisi Mei 1998 memuat berita dengan judul "Hanya dengan Melalui Reformasi Total, Kita Dapat Menciptakan Masyarakat Madani”. Berita ini merupakan ulasan peristiwa wisuda UGM periode III TA 1997/1998. Rektor UGM dalam sambutannya mengangkat tema tentang reformasi, dan judul berita tersebut merupakan kutipan dari pidato Rektor UGM. Warta UGM edisi Juli 1998 halaman pertama memuat berita berjudul "Reformasi Harus Konseptual, Gradual, Kontitusional, Terara, Terukur, dan Teratur. Berita ini berisi ulasan tentang kunjungan Menteri Pendidikan dan Kebudayaan RI ke UGM. Judul berita tersebut diambil dari isi sambutan Menteri Pendidikan dan Kebudayaan UGM saat bertemu dengan jajaran pimpinan UGM. Kabar UGM, sebagai tabloid dwi mingguan yang diterbitkan UGM pada edisi Oktober 2003 pada halaman pertama memuat berita berjudul "Bila UGM Menyikapi Jalan Reformasi”. Berita ini berisi kegiatan Seminar Nasional Meluruskan Jalan Refomasi yang diselenggarakan UGM.

\section{KESIMPULAN}

Berbagai sumber sejarah tentang reformasi yang ada di Arsip UGM menunjukkan bahwa UGM terlibat aktif dalam gerakan reformasi. Elemenelemen yang terlibat dalam gerakan reformasi tersebut meliputi seluruh sivitas akademika UGM dan UGM secara kelembagaan. Elemen-elemen tersebut meliputi dosen, mahasiswa, karyawan, dan kelembagaan UGM. Para dosen UGM baik secara pribadi berperan dalam gerakan reformasi tergabung dalam Tim Nasional yang dibentuk oleh pemerintah untuk merumuskan kebijakan reformasi Indonesia, maupun dengan mendirikan organisasi sosial yang turut mengawal jalannya reformasi. Mahasiswa menjadi pelopor dalam gerakan reformasi ini dan gerakan mahasiswa ini akhirnya meluas dan mendapat dukungan dari seluruh sivitas akademika UGM. Karyawan UGM juga ikut dalam gerakan reformasi dengan ikut aksi demonstrasi dan turut menyampaikan orasi. Bentuk keterlibatan lainnya adalah dengan munculnya pemberitaan di media UGM yang dikelola oleh karyawan UGM seperti Warta UGM yang mengangkat topik berita tentang reformasi. Pemberitaan ini tentu diharapkan dapat menjadi api semangat gerakan reformasi yang diperjuangkan UGM. UGM secara kelembagaan mendorong gerakan reformasi dengan memberikan dukungan, kesempatan, dan fasilitas kepada seluruh sivitas akademika untuk aktif terlibat dalam gerakan reformasi ini. Secara kelembagaan bukti dukungan UGM terhadap gerakan reformasi diantaranya diwujudkan dengan pernyataan sikap UGM. Kelembagaan ini 
bukan hanya tingkat universitas tetapi juga tingkat unit kerja yang ada di UGM seperti fakultas dan pusat studi.

Bentuk-bentuk kegiatan yang dilakukan sebagai taktik gerakan reformasi cukup beragam. Demonstrasi, mendirikan tenda keprihatinan, dan mogok makan adalah taktik yang banyak digunakan oleh mahasiswa. Pernyataan sikap dan membuat forum-forum ilmiah (dialog, seminar, semiloka) pembahasan reformasi merupakan taktik yang dilakukan oleh UGM dan unit kerja (fakultas dan pusat studi) secara kelembagaan. Bentuk gerakan lainnya adalah melakukan kajian untuk merumuskan konsep dan rekomendasi kemudian hasil tersebut kemudian disampaikan sebagai masukan kepada pemerintah dan terlibat dalam tim nasional reformasi, maupun mendirikan yayasan sosial. Penggunaan media tidak luput dari bagian gerakan reformasi. UGM menggunakan media baik media yang dikelola UGM maupun media massa untuk menyampaikan pesan-pesan reformasi dan publikasi reformasi. Berdasarkan sumber-sumber sejarah yang ada di Arsip UGM terlihat bahwa gerakan telah dimulai sejak tahun 1996 berupa demonstrasi mahasiswa yang menyuarakan aspirasi-aspirasi yang akhirnya menjadi tuntutan reformasi seperti pencabutan 5 UU yang dianggap membelenggu demokrasi dan penolakan Soeharto sebagai Presiden hasil pemilu 1997.

Sumber-sumber sejarah terkait reformasi ini khususnya yang menunjukkan keterlibatan UGM dalam gerakan reformasi banyak tersimpan di Arsip UGM. Sumber-sumber sejarah tersebut berupa sumber asli (arsip asli), sumber primer (hasil repro/penggandaan arsip), dan sumber sekunder (penyampaian peristiwa yang disampaikan oleh bukan pelaku utama). Bentuk sumber-sumber sejarah tersebut meliputi arsip tekstual (surat menyurat, pernyataan sikap, siaran pers, kliping media, makalah, hasil kajian) arsip foto kegiatan-kegiatan ilmiah dan demonstrasi, dan arsip rekaman suara hasil oral history programme.

\section{DAFTAR PUSTAKA}

Agger, Ben. 2012. Teori Sosial Kritis: Kritik, Penerapan dan Implikasinya. Diterjemahkan oleh Nurhadi. Cetakan ke tujuh. Kreasi Wacana, Yogyakarta.

Albar, Muhammad Wasith dan M. Fauzi. 2017. Penulisan Sejarah. Kemdikbud, Jakarta.

Bandoro, Adik Bantarso, Eddie Siregar, M. Yogiyanto. 2004. Kampus Biru Menggugah. KAFISIPOLGAMA: Yogyakarta.

Burke, Peter. 1993 History and Social Theory. Cetakan Pertama, Cornell University Press, New York. Terjemahan Mestika Zed dan Zulfami, 2003, Sejarah dan Teori Sosial, Edisi Kedua, Yayasan Obor Indonesia, Jakarta.

Effendi, Sofian. 2004. Curah Gagas Masyarakat Kampus: Rekomendasi untuk Presiden. Edisi ke 2. UGM Press, Yogyakarta.

Kanumoyoso, Bondan. 2017. Metode Sejarah. Kemdikbud, Jakarta.

Laksana, dkk. 2000. Permainan Tafsir Politik Makna di Jalan pada Penghujung Orde Baru. Insist Press bekerjasama dengan Pustaka Pelajar, Yogyakarta.

Laksmi, Tamara Adriani Sosetyo-Salim, Ari Imansyah. 2011. Manajemen 
Lembaga Informasi: Teori dan Praktik. Penaku, Jakarta.

Maliki, Zainuddin. 2012. Rekonstruksi Teori Sosial Modern. UGM Press, Yogyakarta.

Muhaimin, Jahja, dkk. 1985. Kamus Istilah Politik. Depdikbud, Jakarta.

Purwanto, Bambang., Djoko Suryo, dan Soegijanto Padmo. 1999. dari Revolusi ke Reformasi: 50 Tahun Universitas Gadjah Mada. UGM, Yogyakarta.

\section{Sumber Arsip}

1. Keputusan Presiden RI No. 198 Tahun 1998 tentang Pembentukan Tim Nasional Reformasi Menuju Masyarakat Madani (AS3/SC.RF/2)

2. Siaran Pers UGM Seminar Nasional Meluruskan Jalan Reormasi (AS3/SC.SP/3)

3. Hasil Pertemuan Kelompok Reformasi Tim Nasional Reformasi (AS3/SC.RF/4)

4. Bahan Presentasi Kelompok Reformasi Hukum dan PerundangUndangan Tim Nasional Reformasi Tahun 1999 (AS3/SC.RF/3)

5. Hasil Dialog Komisi Kebangsaan: Program Aksi Meluruskan Jalan Reformasi, 2004 (AS3/SC.RF/7)

6. Deklarasi Dialog Komisi Kebangsaan: Program Aksi Meluruskan Jalan Reformasi, 2004 (AS3/SC.RF/7)

7. Kumpulan Makalah Seminar Nasional Meluruskan Jalan Reformasi, 2003 (AS/SC.RP.04/17)

8. Kumpulan Makalah Dialog Kebangsaan Program Aksi Meluruskan Reformasi, 2004 (AS/SC.RP.04/19)

9. Curah Gagas Masyarakat Kampus: Rekomendasi untuk Presiden, 2004. (AS/SC.RP.04/18).
10. Kumpulan Makalah Semiloka Refleksi Kritis terhadap Proses Reformasi, 1999. (AS/PP.MS/304)

11. Warta UGM Mei 1998 (AS/PA.WU/40)

12. Warta UGM Juni 1998 (AS/PA.WU/41)

13. Kabar UGM No. 21/Tahun I/1 Oktober 2003 (AS/PA.KU/15)

14. Foto-foto demonstrasi aksi reformasi di UGM

15. Foto-foto kegiatan ilmiah reformasi di UGM 